\title{
Thermal stability of connective tissue and meat quality of loose structured porcine semimembranosus muscles
}

Liisa Voutila $^{1)}$, Anne Maria Mullen ${ }^{2)}$, Paul Allen $^{2)}$, Declan Troy ${ }^{2)}$, Eero Puolanne ${ }^{1)}$

${ }^{1)}$ Department of Food Technology, University of Helsinki, P.O. Box 66, Viikki EE, Helsinki 00014, Finland, liisa.voutila@helsinki.fi, eero.puolanne@helsinki.fi

${ }^{2)}$ Teagasc, The National Food Centre, Dunsinea, Castleknock, Dublin 15, Ireland, amullen@nfc.teagasc.ie, pallen@nfc.teagasc.ie,dtroy@nfc.teagasc.ie

Loose structure and PSE like zones on the lateral surface of porcine semimembranosus muscle have been observed by other researchers. However the role of connective tissue in this abnormally loose structure in semimembranosus muscle has not yet been clarified. We collected about $100 \mathrm{~g}$ samples from 7 loose structured and 7 normal structured Irish commercial porcine semimembranosus muscles in order to compare the onset and peak of thermal transition temperature of intramuscular connective tissue between the samples from the two groups. Meat quality parameters, ultimate $\mathrm{pH}$, rough estimate for drip loss, lightness (L), redness (a) yellowness (b) and as well as electrical conductivity and reflectance were also measured on the samples. Four of the samples characterized as normal by visual assessment showed DFD characteristic so the statistical analysis was carried out both including and excluding those samples. In both cases the onset $\left(\mathrm{p}<0.001 ; 56.94^{\circ} \mathrm{C}\right.$ vs. $\left.59.82^{\circ} \mathrm{C}\right)$ and peak $\left(\mathrm{p}<0.001 ; 62.59^{\circ} \mathrm{C}\right.$ vs. $\left.64.06^{\circ} \mathrm{C}\right)$ of thermal transition temperature were significantly lower in loose structured meat than in normal structured meat. Also reflectance\% was lower ( $<0.01 ; 45.18 \%$ vs. $69.17 \%$ ) and the colour lighter (higher $\mathrm{L}$ value; $\mathrm{p}<0.01$; 55.05 vs. 45.52 ) and more yellow (higher $b$ value; $p<0.001 ; 18.27$ vs. 14.78 ) in loose structured meat than in normal structured meat when the DFD like samples were excluded. These results indicate that loose structure in porcine semimembranosus muscle could be attributed in part to connective tissue properties possibly in conjunction with PSE effects.

Key Words: Connective tissue, porcine semimembranosus, meat quality, differential scanning calorimetry 


\section{Introduction}

The main roles of connective tissue in muscle are to ensure the passive elastic response of muscle transform the force from muscle fibres into mechanical movement and to mechanically support the vessels and nerves. Collagen is the main protein of all connective tissues and type I collagen is the most abundant one in intramuscular connective tissue (Bailey \& Light 1989, Kjær 2004). Researchers have found that collagen solubility decreases with animal age and varies between muscles and animal species (Hill, 1966; Kovanen et al. 1980; Nakano \& Thompson 1980). This is due to the maturation of collagen cross-links in muscles. Also different proportions of collagen types have an effect on thermal stability of collagen (Bailey \& Light 1989). Thermal stability of collagen has originally been measured to obtain information on the relationship between collagen solubility and meat tenderness (Goll et al. 1963; Carmichael \& Lawrie 1967).

Zones of PSE (pale, soft, exudative) like meat, which are accompanied by loose fibre structure have been observed on the lateral surface of porcine semimembranosus muscle (Minvielle et al. 2001; Franck et al. 2002; Franck et al. 2003; Laville et al. 2005). Risk factors for these zones, seem to include high carcass weight and low ultimate $\mathrm{pH}$ in semimembranosus muscle (Minvielle et al. 2001). There are also studies showing that PSE zones appear in higher percentage of hams from pigs carrying $n$ allele at HAL locus (Aubry et al. 2000) and $\mathrm{RN}^{-}$allele at the $\mathrm{RN}$ locus (Le Roy et al. 2001). Higher collagen solubility, glycolytic potential, free glucose, glucose-6-phosphate and lactate have been observed in defective muscles compared to normal muscles (Minvielle et al. 2001).

This loose structured meat is also characterised by the ease at which bundles can be pulled away by hand (personal observations on Finnish and Irish samples). It is possible that these abnormalities can be attributed in part to connective tissue properties. Therefore it would be of interest to study these properties and any subsequent influence on quality attributes.

The objective of this study was to compare thermal stability of connective tissue from normal and loose structured semimembranosus muscle and to measure general meat quality parameters of the two groups of meat.

\section{Methodology}

Porcine semimembranosus muscles were visually assessed at $24 \mathrm{hr}$ postmortem in the boning hall of commercial abattoirs in Ireland following standard slaughter, chilling and boning procedures. Approximately $100 \mathrm{~g}$ of sample was taken from muscles showing 'loose structure' $(\mathrm{n}=7)$ and 'normal structure' (n=7) (photo 1).

On return to The National Food Centre, reflectance [Opto-star (SFK technology, Denmark)], conductivity [Pork Quality Meter (PQM) (Inteck GmbH, Industriestrabe 9, D-86551 Aichach, Germany)] and colour [Miniscan XE Plus (Hunter Associates Laboratory Inc., Virginia, USA)] measurements were recorded on all samples. A rough estimate of drip loss was obtained by holding the samples (approx. $100 \mathrm{~g}$ ) at $+1^{\circ} \mathrm{C}$ for three days (modification of method of Honikel 1998). $\mathrm{pH}$ was recorded after drip loss assessment [meter model no: 420A (Orion Research Inc., Boston, MA 02129, USA); Amagruss pH electrode ( $\mathrm{pH} / \mathrm{mV}$ Sensors Ltd., Murrisk-Westport, Co. Mayo, Ireland)]. Meat was blended with Robot coupe blender (R301 Ultra, Robot coupe SA, France) in order to blend the drip back into meat before pH measurements. Results for individual meat samples for reflectance, conductivity and colour were an average of four readings across each sample surface.

Connective tissue was extracted from myofibril proteins according to King (1987) and Aktas \& Kaya (2001) with few modifications. Thermal properties of connective tissue were determined in Differential Scanning Calorimeter DSC2010 with refrigerating cooling system (RCS) (TA Instruments, AGB Scientific, Dublin, Ireland). The samples were heated $+10-+95^{\circ} \mathrm{C}$ with the rate $5^{\circ} \mathrm{C} / \mathrm{min}$ in the DSC which was calibrated with mercury $\left(\mathrm{mp}-38.8^{\circ} \mathrm{C}, \Delta \mathrm{Hm} 11.4 \mathrm{Jg}-1\right)$ distilled water $\left(\mathrm{mp}-0.0^{\circ} \mathrm{C}, \Delta \mathrm{Hm}\right.$ $334.5 \mathrm{Jg}-1$ ), gallium (mp $29.8^{\circ} \mathrm{C}, \Delta \mathrm{Hm} 80 \mathrm{Jg}-1$ and indium (mp $156.6^{\circ} \mathrm{C}, \Delta \mathrm{Hm} 28.45 \mathrm{Jg}-1$ ). Both the onset temperature and the peak of thermal transition temperature of connective tissue were recorded from the thermogram. Statistical analysis was carried out using SPSS12 (SPSS 12.0.1 for Windows). 


\section{Results \& Discussion}

Following analysis of the data it was noted that a number of the 'normal structure' muscles were exhibiting DFD like characteristics. Therefore statistical analyses were conducted including and excluding these data. Table 1 shows the results obtained with the DFD like muscles removed. No significant differences were noted in ultimate $\mathrm{pH}\left(\mathrm{pH}_{\mathrm{u}}\right)$, conductivity, Hunter a value and drip loss values. Colour in loose structured meat was lighter (L), more yellow (b) and had higher Reflectance\% than in 'normal structured' meat. This was anticipated as 'loose structured' muscle was visibly paler.

The onset and peak of thermal transition temperature of connective tissue (in Table 1.) measured with DSC were lower $(\mathrm{p}<0.001)$ in loose structured meat than in normal structured meat. Although the number of samples was very small the results were statistically significant. It was interesting to note that when the full set of data was analysed ( $\mathrm{n}=7$ for both groups) similar results were obtained (results not presented). As the selection of samples was based on visual structure this is not so surprising. Franck et al. (2002) concluded that the defective semimembranosus muscles show PSE characteristics, low pH at 30-45 post mortem with high temperature and lower $\mathrm{pH}_{\mathrm{u}}$ than normal looking meat. It was not feasible in this experiment to obtain early post mortem $\mathrm{pH}$ data therefore we do not have direct evidence of fast $\mathrm{pH}$ fall which could have related the loose structure to PSE defect. Although, Horgan et al. (1991) already found that decreasing the $\mathrm{pH}$ of connective tissue decreases the thermal transition temperature. They also noted that in addition to $\mathrm{pH}$ thermal transition temperature of connective tissue is dependent on the composition of the cross-links of collagen. Even though the conditions of Horgan et al. (1991) study were not corresponding to raw meat, this could indicate that lower $\mathrm{pH}_{\mathrm{u}}$ in loose structured muscles had some effect on connective tissue by lowering the thermal transition temperature. Also findings of Aktas \& Kaya (2001) support the theory that low $\mathrm{pH}_{\mathrm{u}}$ lowers thermal transition temperature. After marinating connective tissue in lactic acid they recorded thermal transition temperatures around $39^{\circ} \mathrm{C}$ which was $23-25^{\circ} \mathrm{C}$ lower than that of control group but again, the conditions were not corresponding to raw meat.

Table 1. Mean values and standard deviations of meat quality and DSC traits of loose and normal structured pork semimembranosus muscles.

\begin{tabular}{lccc}
\hline & Loose $(\mathrm{n}=7)$ & Normal $(\mathrm{n}=3)$ & $\mathrm{P}$ \\
$\mathrm{pH}($ day 3) & $5.63 \pm 0.128$ & $5.79 \pm 0.038$ & \\
$\mathrm{~L}$ (day 3) & $55.05 \pm 3.311$ & $45.52 \pm 2.794$ & $* *$ \\
$\mathrm{a}($ day 3) & $10.88 \pm 1.948$ & $8.98 \pm 1.529$ & \\
$\mathrm{~b}$ (day 3) & $18.27 \pm 1.074$ & $14.78 \pm 0.528$ & $* * *$ \\
Conductivity (day 1), mS/cm & $14.07 \pm 0.588$ & $11.52 \pm 4.003$ & \\
Reflectance (day 1), \% & $45.18 \pm 8.013$ & $69.17 \pm 6.526$ & $* *$ \\
Rough estimate for drip loss, \% & $3.5 \pm 2.03$ & $2.0 \pm 1.06$ & \\
DSC onset, ${ }^{\circ} \mathrm{C}$ & $56.94 \pm 0.784$ & $59.82 \pm 0.766$ & $* * *$ \\
DSC peak, ${ }^{\circ} \mathrm{C}$ & $62.59 \pm 0,396$ & $64.06 \pm 0,397$ & $* * *$ \\
\hline
\end{tabular}

$* * * \mathrm{p}<0.001 * * \mathrm{p}<0.01$ 


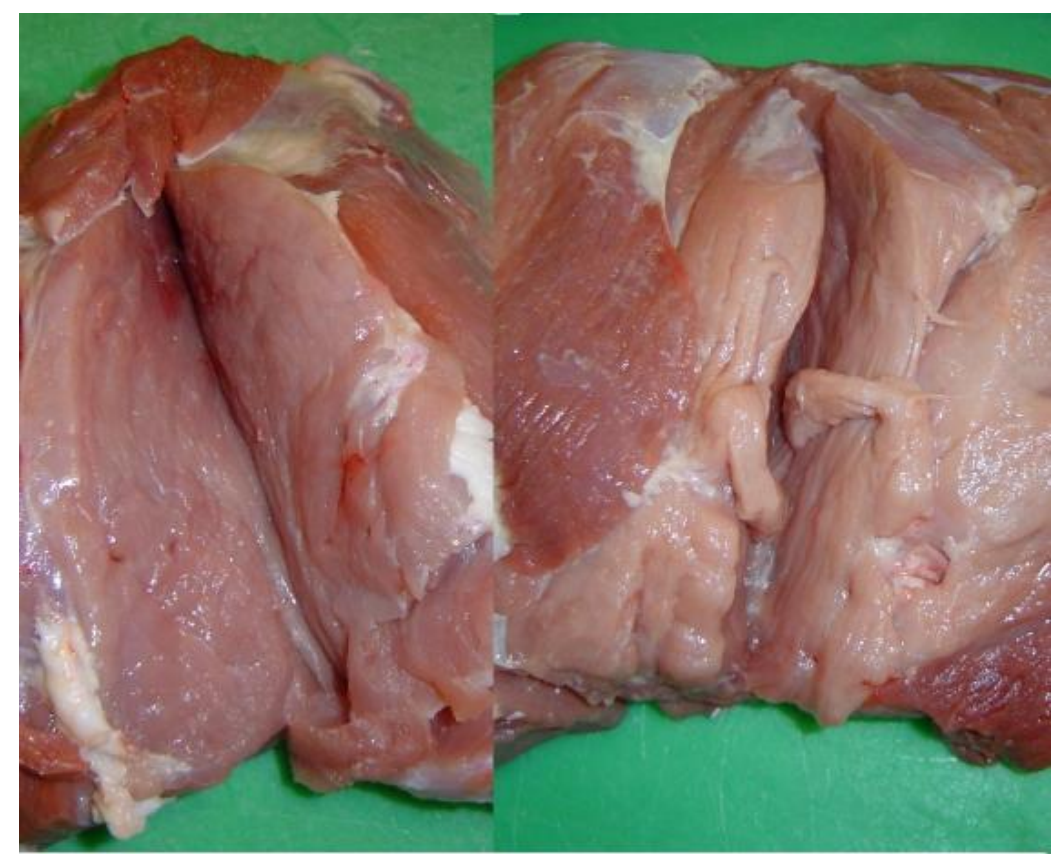

Photo 1. Examples of 'normal structure' (RHS) and 'loose structure' (LHS) semimembranosus muscle.

\section{Conclusions}

Thermal properties of connective tissue were compared in 'loose structure' and 'normal structure' porcine semimembranosus muscles. A significantly lower thermal transition temperature of intramuscular connective tissue was observed in the 'loose structure' muscle. It would be interesting to further clarify the role of connective tissue in weakening of the structure in semimembranosus muscles and the interaction with meat quality characteristics.

\section{Acknowledgements}

This study was carried out at Teagasc, The National Food Centre, Ireland by financial support of the European Union Framework (Marie Curie Training Site Aware) and at the University of Helsinki, Finland funded by the Finnish Ministry of Agriculture and Forestry.

\section{References}

Aktas, N. and Kaya, M. (2001). Influence or weak organic acids and salts on the denaturation characteristics of intramuscular connective tissue. A differential scanning calorimetry study. Meat Sci. 58: 413-419.

Aubry, A., Ligonesche, B., Gueblez, R. and Gaudré, D. (2000). Comparaison de porcs charcutiers NN et Nn pour les performances de croissance, carcasse et qualité de viande, et l'aptitude à produire du jambon cuit. Journées Rech. Porcine France 32, 361-367.

Bailey, A. J. and Light, N. D. (1989). Connective tissue in meat and meat products. (1st ed.). Elsevier Science Publishers, Essex.

Carmichael, D. J. and Lawrie, R. A. (1967). Bovine collagen. Changes in collagen solubility with animal age. J. Food Technol. 2, 299-311.

Franck, M., Monin, G., Figwer, P., Poirel, M. T. and Legault, C. (2002). Strukturloses Fleisch - ein ernsthaftes Problem. Problematik bei der industriellen Herstellung von Kochschinken. Fleischwirtschaft 12, 97-100.

Franck, M., Svensson, M., von Seth, G., Josell, A., Figwer, P., Poirel, M. T. and Monin, G. (2003). Effect of stunning conditions on occurrence of PSE defects in hams of rn+/RN- pigs. Meat Sci. 64, 351-355.

Goll, D. E., Bray, R. W. and Hoekstra, W. G. (1963). Age-associated changes in muscle composition. The isolation and properties of a collagenous residues from bovine muscle. J. Food Sci. 28, 503-509.

Hill, F. (1966). The solubility of intramuscular collagen in meat animals of various ages. J. Food Sci. 31, 161-166. 
Honikel, K. O. (1998). Reference methods for the assessment of physical characteristics of meat. Meat Sci. 49, 447457.

Horgan, D. J., Kurth, L. B., and Kuypers, R. (1991). pH effect on thermal transition temperature of collagen. J. Food Sci. 56, 1203-1204.

King, N. L. (1987). Thermal transition of collagen in ovine connective tissues. Meat Sci. 20, 25-37.

Kjær, M. (2004). Role of extracellular matrix in adaptation of tendon and skeletal muscle to mechanical loading. Physiol. Rev. 84, 649-698.

Kovanen, V., Suominen, H. and Heikkinen E. (1980). Connective tissue of "fast" and "slow" skeletal muscle in rats - effects of endurance training. Acta Physiol. Scand. 108, 173-180.

Laville, E., Sayd, T., Santé-Lhoutellier, V., Morzel, M., Labas, R., Franck, M., Chambon, C. and Monin, G. (2005). Characterisation of PSE zones in semimembranosus pig muscle. Meat Sci. 70, 167-172.

Le Roy, P., Monin, G., Kérisit, R., Jeanot, G., Caritez, J.C., Amigues, Y., Lagant, H., Boulard, J., Billon, Y., Elsen, J.M. and Sellier, P. (2001). Effets interactifs des gènes RN et HAL sur la qualité de la viande; résultats obtenus lors de la fabrication de jambon cuit prétranché. Journées Rech. Porcine France 33, 103-110.

Minvielle, B., Le Strat, P., Lebret, B., Houix, Y., Boulard, J. and Clochefert, N. (2001). Viandes déstructurées. Situation dans cinq abattoirs de l'Ouest de la France: facteurs de risque et proposition d'un modèle. Caractérisation colorimétrique, biochimique et histologique. Journées Rech. Porcine France 33, 95-101.

Nakano, T. and Thompson, J. R. (1980). Age- and sex-associated changes in chemical composition of bovine triceps brachii intramuscular and epimysial connective tissue with emphasis on glycosaminoglycans. Can. J. Anim. Sci. 60, 643-662. 